\title{
Construction and demolition waste in concrete: property of pre-molded parts for paving
}

\author{
J.T.M.Francisco ${ }^{1 *}, A$. E. de Souza ${ }^{1}$, S. R. Teixeira ${ }^{1}$ \\ ${ }^{1}$ Universidade Estadual Paulista, UNESP, FCT, Presidente Prudente, SP, Brazil
}

\begin{abstract}
Construction and demolition waste (CDW) production is a growing factor on a global scale and its incorrect disposal becomes an increasingly common problem in cities. It is estimated to represent, on average, 50\% of the urban solid waste mass in the world. In this sense, an alternative to the destination is their reuse. In this work, the properties of interlocking concrete pieces for paving with the CDW in substitution to large aggregates were analyzed. The substitution occurred in fractions from 20 to $100 \mathrm{wt} \%$ of CDW in cylindrical test specimens to find the ideal substitution content, so that to prepare pre-molded concrete blocks. The piece properties obtained were analyzed according to Brazilian standards for compressive strength and water absorption. Therefore, the influence of the residue incorporation in the pieces, from the technical viewpoint, was verified. The sample that presented the best performance had a substitution of $20 \%$ of the natural aggregate by crushed CDW.
\end{abstract}

Keywords: interlocking paving, concrete, construction and demolition waste, CDW.

\section{INTRODUCTION}

The construction and demolition waste (CDW) production is an unavoidable fact. The growth of cities and the population increase, together with the rise of raw materials extraction, lead to several environmental and social problems. Incorrect disposal of these wastes in irregular landfills or in inappropriate places promotes habitat destruction, contamination of groundwater, soil and the atmosphere [1], and acts as a shelter for animals harmful to human health. The politics used by the government with respect to construction and demolition waste is characterized, in most cases, by corrective actions, generating enormous indirect social costs for the society. Civil construction waste (CCW) or construction and demolition waste (CDW) comes from repairs and demolitions of civil works, renovations and those resulting from the land preparation and excavation [2]. Many scientific studies have been published about the CDW use, looking for innovative materials, cleaner products, and processes, in order to mitigate the environmental impacts generated by the construction sector [3]. Other studies are focused on the generation, characterization, and management of CDW $[4,5]$. To develop new products, several studies have been conducted on the incorporation of CDW: in clays for the ceramic bricks manufacture [6, 7], concrete [8-10], concrete paving [11], for masonry and mortars artifacts $[4,12,13]$. These studies show the influence of the added volume, particle size and CDW composition on the final properties of the materials produced.

In Brazil, every year, the construction industry produces a huge volume of waste from construction and demolition processes, estimated at $500 \mathrm{~kg} /$ inhabitant/year, may vary

*joycetatiani@hotmail.com

(D) https://orcid.org/0000-0002-8191-6322 according to the human development index (HDI) [12]. In the year 2016, only CDW collection was 45.1 million, and the total percentage generated in the municipalities is even greater since the municipalities collect only the waste abandoned or launched in the public places [14]. In this context, it is necessary a correct management of the CDW, so that its destination reaches a nobler potential use. It is possible through the recycling of its components by the transformation into recycled aggregates to form, for example, pre-molded concrete pieces for interlocking paving for use on urban roads. Interlocking paving is considered a flexible paving that has several layers, the outer paving being made up of concrete pieces juxtaposed with each other and filled by a grout material [15]. On layers previously prepared, pre-molded concrete pieces, commonly called slabs, blocks, parallelepipeds, pavers or drainage pavements, are placed: first on a sand layer, followed by the base, sub-base, and subgrade [16]. In addition, they must have adequate dimensions, compressive strength, abrasion resistance, water absorption, and other characteristics in accordance with the appropriate standards. In an unpublished previous work, it was observed that the presence of small aggregates $(<4.8 \mathrm{~mm})$ in specimens prepared with $100 \%$ by weight of CDW impaired the mechanical strength of the test bodies. In this sense, this research proposes to study the use of crushed construction waste by replacing natural aggregate (gravel) in pre-molded concrete parts for paving, by applying the current Brazilian standards, aiming at reaching the properties required for manufacturing the pieces.

\section{MATERIALS AND METHODS}

Materials characterization: based on previous results, the proportions of $50 \%, 35 \%$ and $15 \%$ of concrete, ceramic and mortar, respectively, were adopted as a reference, for 
the average CDW composition. A pre-selection and CDW collection were made in construction buckets, located in the Presidente Prudente city, São Paulo State. The residues were crushed using a knife mill and mixed in the 50:35:15 composition. As the objective of the work was the replacement in the concrete of the gravel by CDW, only the large fraction was used, between 4.8 and $26 \mathrm{~mm}$. For the determination of granulometric composition, a stirrer and a sieve set $(4.8-19 \mathrm{~mm})$ were used, in accordance with NBR 7217 standard [17]. The selected fractions were oven dried and weighed using a semi-analytical balance to determine each percentage. For the specific mass, apparent specific mass and water absorption determination, the samples were immersed in water (for $24 \mathrm{~h}$ ) using a wire basket, weighed and dried in an oven according to NBR NM 53 standard [18]. For the unit mass and volume of voids determination, a container with an approximate volume of $0.015 \mathrm{~m}^{3}$ and a balance with $50 \mathrm{~kg}$ maximum capacity were used, in accordance with ' $\mathrm{C}$ method' of the NBR NM 45 standard [19]. The CDW sample was ground, passed through a 170 mesh screen (aperture 88 $\mu \mathrm{m})$ and subjected to X-ray diffraction (XRD) analysis for the determination of crystalline phases present in the CDW sample; an X-ray diffractometer Shimadzu, XRD-6000, was used.

Trace composition determination: a concrete dosage study was performed to define the reference trace (without residue), based on the IPT/EPUSP method [20], which consists of a predominantly experimental method. The optimum fine fraction (mortar) content of the concrete was set at $54 \%$ and the cone trunk abatement at $10 \pm 5 \mathrm{~mm}$, as an intermediate trace. Then two more traces were made, one above and one below the cement fraction, and the specimens were molded for compressive strength (CS) determination. With the results, a dosage diagram was developed, in which it correlated compressive strength, water/cement ratio $(\mathrm{w} / \mathrm{c})$, unit trace (ut) and cement consumption (cc) (Fig. 1). The reference trace (1:4.14 or 1:1.77:2.37, for cement, sand, and gravel, respectively) adopted in the study was obtained from Fig. 1: starting from $40 \mathrm{MPa}$, a line parallel to the axis w/c was drawn until reaching the $\mathrm{CS} \times \mathrm{w} / \mathrm{c}$ curve (Fig. 1a); from this point, a vertical line was drawn up to the line in the relation ut $\times$ w/c (Fig. 1b); from this point, a line parallel to the axis of the w/c ratio (to the left), was drawn until reaching the utxcc curve (Fig. 1c). The application of this method resulted in the following values: $0.385 \mathrm{w} / \mathrm{c}$ ratio; 1:4.14 trace and $398.75 \mathrm{~kg} / \mathrm{m}^{3}$ cement consumption. The 40 MPa value, $14.28 \%$ above the minimum strength established by NBR 9781 standard (35 MPa, for light vehicles) [15] was chosen considering that the use of recycled waste tends to decrease the piece strength.

Specimen preparation: all specimens were prepared using CP II-Z-32 cement, with dimensions: $10 \mathrm{~cm}$ in diameter and $20 \mathrm{~cm}$ in height. Before the incorporation of the recycled aggregates into the composition of the traces, it was verified the need to pre-wet them, since the recycled aggregates with high porosity alter the water amount in the mixtures, which can affect the concrete properties in the hardened state and

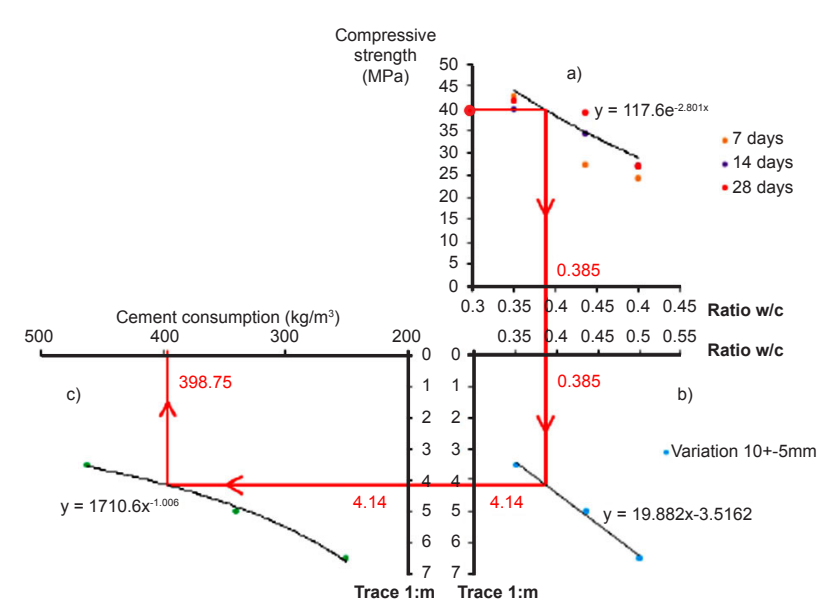

Figure 1: Dosage diagram used to determine the reference trace.

also their hydration [16]. Nine cylindrical specimens were prepared for each composition: reference trace and five traces with $20,40,60,80$ and $100 \%$ replacement of the large aggregate by crushed and moistened CDW, totalizing 54 specimens. The concrete was mixed using a concrete mixer and the molds with the concrete were densified using a vibrating table. The specimens were demolded after $24 \mathrm{~h}$, identified and stored in a humid chamber until the stipulated breaking age ( 7 and 28 days) was reached. The specimens were subjected to a surface leveling (capping), using molten sulfur to provide a homogeneous distribution of the force applied during the compression test. Before laying the concrete in the fresh state in the molds, a slump test was performed, depositing the mass in a metallic mold in the cone trunk format in which its mass was divided into three equal parts applying 25 strokes in each layer with a density rod. The mold was removed and the difference between the rod and the mold, which is the concrete abatement (NBR NM 67 [21]), was measured with a tape measure.

Specimens characterization: the compressive strength tests were performed at the established ages, in accordance with NBR 5739 Brazilian standard [22], using an EMIC 100 universal press. The water absorption by immersion, void index and specific mass of the specimens were determined using a semi-analytical balance. The specimens were submitted to drying using an oven, immersed in water, and weighed according to all the parameters defined in NBR 9778 standard [23]. All measurements were performed in triplicate.

Pre-molded concrete pieces: from the results obtained with the specimens, 3 hexagonal concrete pieces and 6 rectangular pieces for each sample were made, following the methodology used in the specimen preparation. In the pre-molded pieces preparation, the hexagonal shape had 8 $\mathrm{cm}$ thickness, $30 \mathrm{~cm}$ longitudinal dimension and each side edge measured $18 \mathrm{~cm}$. According to NBR 9781 standard, this hexagonal piece is characterized as Type III pieces, weighing more than $4 \mathrm{~kg}$. The rectangular pieces had $8 \mathrm{~cm}$ thickness, $24 \mathrm{~cm}$ length, and $14 \mathrm{~cm}$ width. The hexagonal pieces were submitted only to the water absorption test [15] 
and the rectangular pieces were rectified with cement paste on both sides and submitted to the compression test.

\section{RESULTS AND DISCUSSION}

XRD pattern of the CDW powder showed two main identified phases: silicon oxide (quartz- $\alpha$ ), mainly from sand, and calcium carbonate (calcite) from the mortar lime (Fig. 2). This silicon oxide was well crystallized and did not contribute to the reactions that occurred during the curing of concrete.

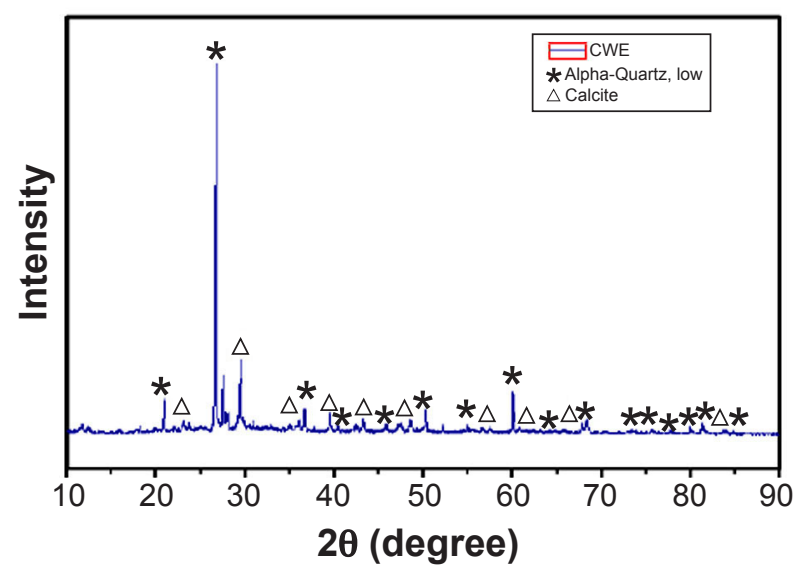

Figure 2: XRD pattern of CDW powder.

As the ceramic residue was more porous than the other materials that composed the concrete, it caused an increase in water absorption and consequently in the water/ cement ratio $[9,11]$. Therefore, the higher its percentage in concrete, the greater the water amount required in the mixture. Other studies $[13,24]$ showed that $10 \mathrm{~min}$ of prewetting is sufficient so that the trace preparation did not become a time-consuming process and it was found that, in this time, CDW absorbed more than $95 \%$ of the water that would be absorbed in $24 \mathrm{~h}$. On the other hand, if the ceramic material releases part of this water to the concrete, this water excess could damage the final strength of piece $[13,24]$. In the slump test, it was observed that the higher CDW concentration in the concrete, the higher was the cone

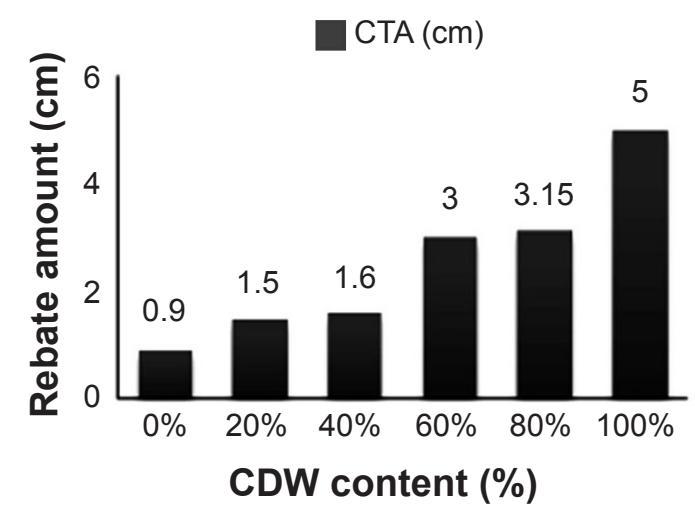

Figure 3: Cone trunk abatement (CTA) with a cylindrical proof probe of the specimens with different CDW content. trunk abatement (CTA), for the same water/cement ratio (Fig. 3). Since all parameters were unchanged, the increase in the CTA value was attributed to the release of water by the $\mathrm{CDW}$, mainly by the ceramic material.

Granulometry tests (Fig. 4) showed that the particle size distribution curve of CDW was closer to gravel $1 / 2$ (2.4 up to $19 \mathrm{~mm}$ ) than gravel 1 (6.3 up to $19 \mathrm{~mm}$ ). Therefore, crushed stone $1 / 2$ was used in all procedures. In the grain size curves, it was observed that despite the differences between the natural aggregate and the crushed CDW, the granulometric distributions were similar between these materials, which passed about $80 \%$ through the intermediate series sieve with $12.5 \mathrm{~mm}$ opening.

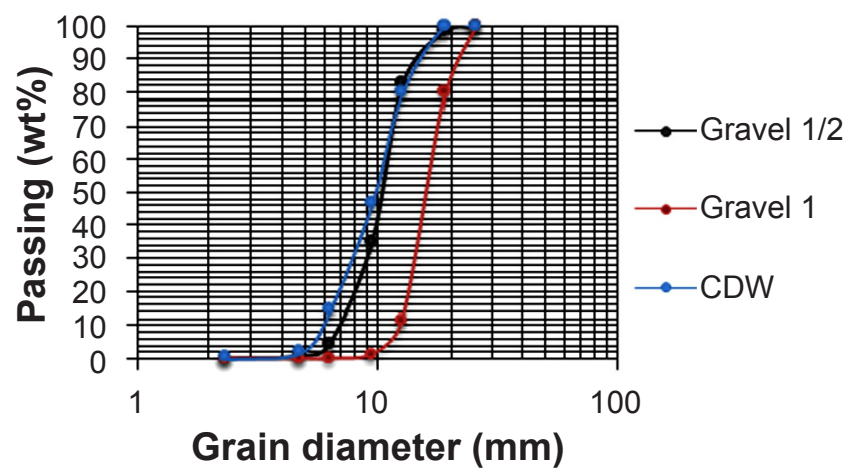

Figure 4: Granulometric curves obtained for gravel $1 / 2$, gravel 1 and CDW.

Table I summarizes the test results for specific mass, apparent specific mass, water absorption, and unit mass determination. As expected, it was verified that the CDW had lower specific mass and unit mass. But it presented about seven times higher water absorption in relation to the natural aggregate (gravel), which was within the absorption parameter allowed by the standard $(\leq 12 \%)$ [24, 25], mainly due to its high porosity $[9,12,26]$. Also, the CDW specific mass was smaller than the reference aggregate [10], associated with the presence of more porous material in the residue composition. Although the water absorption was higher, the lower specific mass for the CDW allowed the production of samples relatively lighter than those obtained with natural aggregate.

Fig. 5 presents the average compressive strength values obtained at 7 and 28 days of the specimens with gravel replaced by $\mathrm{CDW}$ in $0,20,40,60,80$ and $100 \%$. The results showed that there was a continuous decrease in the mechanical strength of the concrete with the increase in CDW percentage. This reduction in strength was due to the CDW composition and mainly to the presence of ceramic material, that presents greater porosity and less mechanical strength than the gravel. After 28 days of curing, only the specimens with $20 \%$ substitution for CDW reached the minimum strength required by the Brazilian standard ( $\geq 35$ $\mathrm{MPa}$ ), presenting strength of $37.61 \mathrm{MPa}$. This composition can allow its use for the fabrication of pieces for sidewalks and traffic of light vehicles paving, according to Brazilian standard [15]. This value may change according to the 
Table I - Specific mass, water absorption and unit mass of aggregates (gravel and CDW).

\begin{tabular}{|c|c|c|c|c|c|c|c|}
\hline \multirow{2}{*}{ Aggregate } & \multirow{2}{*}{$\begin{array}{c}\text { Maximum } \\
\text { diameter }(\mathrm{mm})\end{array}$} & \multirow{2}{*}{$\begin{array}{l}\text { Fineness } \\
\text { module }\end{array}$} & \multicolumn{3}{|c|}{ Specific mass $\left(\mathrm{g} / \mathrm{cm}^{3}\right)$} & \multirow{2}{*}{$\begin{array}{c}\text { Absorption } \\
(\%)\end{array}$} & \multirow{2}{*}{$\begin{array}{l}\text { Unit mas } \\
\left(\mathrm{g} / \mathrm{cm}^{3}\right)\end{array}$} \\
\hline & & & SSS & Dry & Apparent & & \\
\hline CDW & 12.5 & 2.50 & 2.34 & 2.72 & 2.12 & 10.38 & 1.22 \\
\hline Gravel & 19.0 & 2.66 & 2.97 & 3.07 & 2.93 & 1.52 & 1.55 \\
\hline
\end{tabular}

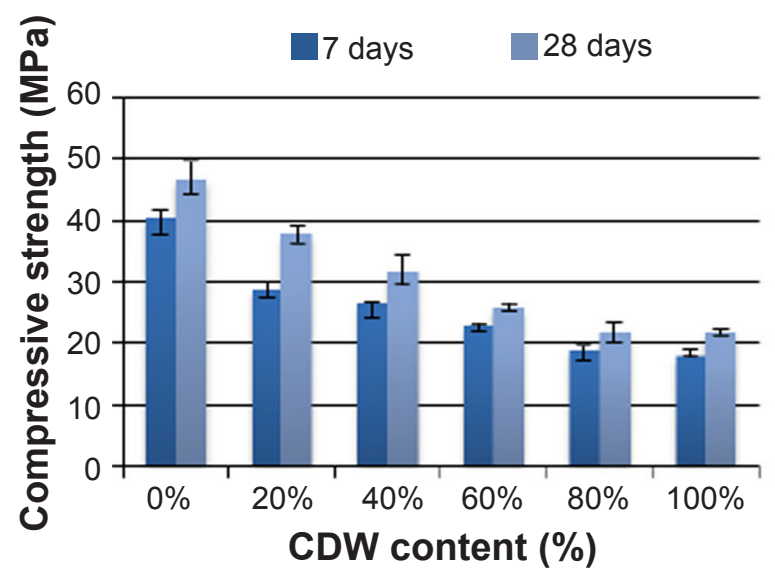

Figure 5: Compressive strength of cylindrical specimens.

regulations of each country [27]. In the study [28], a similar value was found (29.6 MPa), however, replacing $25 \mathrm{wt} \%$ of the concrete aggregate by crushed ceramic blocks. It was reported that this replacement percentage decreases the compressive strength by about $37 \%$ when compared to the pure sample (28 days). In our case, this decrease was approximately $18 \%$. The other compositions, with substitutions above $20 \%$, had mechanical strength higher than $20 \mathrm{MPa}$, after 28 days, which is the minimum value required for structural concrete [9].

Table II shows the water absorption results for the specimens without CDW and with 20\% CDW. As expected, it was observed that specimens containing CDW showed higher water absorption when compared to reference trace specimens, without CDW. This is due to the presence of ceramic material with a higher void content (open porosity). In the same way, the ceramic material decreased the dry saturated and real specific mass of the specimens with CDW. These results corroborate the study [28], which presented higher values of water absorption and smaller specific mass for samples with $25 \mathrm{wt} \%$ of crushed ceramic blocks in substitution to the concrete aggregate. In this case, the presence of ceramic aggregates was responsible for this variation. In the studies [28, 29], the reference blocks already presented higher values of water absorption and specific mass than those found in our study.

The water absorption and compression tests, presented below, were done using pieces with the reference trace and with $20 \% \mathrm{CDW}$ incorporated in the mixture, which corresponded to that considered as the ideal replacement in this work. Fig. 6 shows the water absorption results for the hexagonal blocks. It can be stated that the pieces containing
Table II - Water absorption by immersion, voids index and specific mass for the specimens.

\begin{tabular}{lccccc}
\hline Specimen & $\begin{array}{c}\text { Absorption } \\
(\%)\end{array}$ & $\begin{array}{c}\text { Voids } \\
\text { index } \\
(\%)\end{array}$ & \multicolumn{3}{c}{ Specific mass $\left(\mathrm{g} / \mathrm{cm}^{3}\right)$} \\
& & Saturated & Real \\
\hline Reference & 5.95 & 16.30 & 2.74 & 2.90 & 3.27 \\
$20 \%$ CDW & 7.24 & 19.98 & 2.62 & 2.81 & 3.23 \\
\hline
\end{tabular}

CDW demonstrated excellent performance compared to the parameters established by the standard [15], whose maximum average value is $6 \%$, not being accepted any value that exceeds $7 \%$ of absorption. The pieces without residue incorporated in the trace resulted in $4.07 \%$ of absorption, whereas those with $20 \%$ CDW showed $4.41 \%$ (Fig. 6), that is, $0.34 \%$ more than the first one. The presence of CDW in the concrete, as already mentioned, increased the water absorption due to its greater porosity.

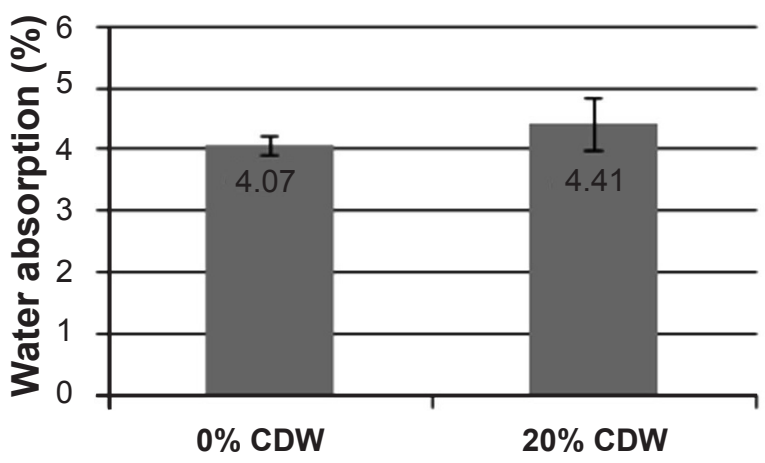

Figure 6: Water absorption of the hexagonal pieces for paving.

In Fig. 7, the results regarding the axial compression of the rectangular pieces are shown. It is worth noting that

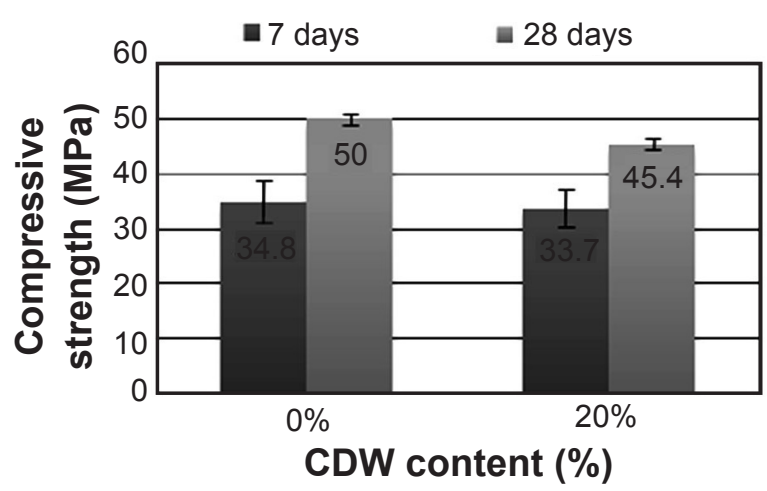

Figure 7: Compressive strength of rectangular pieces. 
the rectangular pieces presented an excellent performance ( $>45 \mathrm{MPa}$ ), as well as for the cylindrical specimens ( $>35$ $\mathrm{MPa}$ ), for 28 days of curing, meeting the Brazilian standard requirement [15]. For the compression test, the use of the rectangular pieces was necessary since the standard requests that the piece width does not exceed $140 \mathrm{~mm}$.

\section{CONCLUSIONS}

Due to the higher water absorption by the CDW, it was observed that the pre-humidification of residue, before mixing, is fundamental to obtain the results presented in this work. The humidification influence varied with the CDW percentage added, as it released water and influenced the water/cement ratio. From the characterization, analysis and tests performed, it was observed that the aggregate replacement by the crushed CDW, despite damaging the concrete properties, presented an excellent performance comparing to the values established by the technical standards. Samples with 20\% CDW substituting aggregate, after 28 days of curing, showed a minimum compressive strength greater than $35 \mathrm{MPa}$, which is the limit established by the Brazilian standard. In addition, due to the presence of ceramic material, with higher porosity and void index, samples with CDW had a lower specific mass than those without CDW in their composition. These results showed that the replacement of gravel by up to $20 \% \mathrm{CDW}$ in concrete for pre-molded pieces is feasible considering the Brazilian standards. Therefore, the CDW reuse in this product type can lead to an immediate consequence of reducing improperly accumulated waste in the environment, in addition resulting in less consumption of raw material in the construction industry.

\section{ACKNOWLEDGMENTS}

To POSMAT/UNESP, LEC/UNOESTE and CAPES for the scholarship granted.

\section{REFERENCES}

[1] R.H. Crawford, D. Mathur, R. Gerritsen, in Proc. Eng. Creative Constr. Conf., Croatia (2017).

[2] Min. Meio Amb., CONAMA, Resol. no 307 (2002).

[3] P. Ghisellini, X. Ji, G. Liu, S. Ulgiati, J. Clean Prod. 195 (2018) 418.

[4] H. Carasek, A.C.C. Girardi, R.C. Araújo, R. Angelim, O. Cascudo, Cerâmica 64,370 (2018) 288.

[5] M. Menegaki, D. Damigos, Curr. Opin. Green Sustain. Chem. 13 (2018) 8.

[6] S.N. Monteiro, C.M.F. Vieira, Constr. Build. Mater. 68 (2014) 599.

[7] M.G.T. Gaspareto, S.R. Teixeira, Cerâm. Ind. 22 (2017) 40.
[8] S. Shahidan, M.A.M. Azmi, K. Kupusamy, S.S.M. Zuki, N. Ali, Procedia Eng. 174 (2017) 1028.

[9] A.P. Stroher, D.S. Kato, N.U. Yamaguchi, O.M.C. Junior, Cerâm. Ind. 22 (2017) 34.

[10] P.R.L. Lima, M.B. Leite, E.Q.R. Santiago, Waste Manag. 30 (2010) 1107.

[11] S.R. Teixeira, C.B. Martins, A.E. Souza, W. Caldeira, J. Solid Waste Technol. Manage. 1 (2017) 366.

[12] M. Contreras, S.R. Teixeira, M.C. Lucas, L.C.N. Lima, D.S.L. Cardoso, G.A.C. Silva, G.C. Gregório, A.E. Souza, A. Santos, Constr. Build. Mater. 123 (2016) 594.

[13] J.O. Malta, V.S. Silveira, J.P. Gonçalves, R.D.T. Filho, Amb. Constr. 14 (2014) 85.

[14] ABRELPE, "Panorama dos resíduos sólidos no Brasil 2016", <http://www.abrelpe.org.br/>, ac. 01/07/2017.

[15] ABNT, NBR 9781, "Peças de concreto para pavimentação - especificação e métodos de ensaio", Rio de Janeiro (2013).

[16] P.K. Gautam, P. Kalla, A.S. Jethoo, R. Agrawal, H. Singh, Constr. Build. Mater. 180 (2018) 239.

[17] ABNT, NBR 7217, "Agregados - determinação da composição granulométrica”, Rio de Janeiro (1987).

[18] ABNT, NBR NM 53, “Agregado graúdo - determinação de massa específica, massa específica aparente e absorção de água" (errata 1), Rio de Janeiro (2003).

[19] ABNT, NBR NM 45, "Agregados - determinação da massa unitária e do volume de vazios", Rio de Janeiro (2006).

[20] P.R.L. Helene, P. Terzian, Manual de dosagem $e$ controle do concreto, PINI, S. Paulo (1992).

[21] ABNT, NBR NM 67, "Concreto - determinação da resistência pelo abatimento de tronco de cone", Rio de Janeiro (1998).

[22] ABNT, NBR 5739, "Concreto - ensaio de compressão de corpos de prova cilíndricos", Rio de Janeiro (2007).

[23] ABNT, NBR 9778, “Argamassa e concreto endurecidos - determinação da absorção de água, índice de vazios e massa específica" (Errata 2), Rio de Janeiro (2005).

[24] J.A. Carneiro, P.R.L. Lima, M.B. Leite, R.D.T. Filho, Cement Concrete Comp. 46 (2014) 65.

[25] ABNT, "Agregados reciclados de resíduos sólidos da construção civil - utilização em pavimentação e preparo de concreto sem função estrutural - requisitos", Rio de Janeiro (2004).

[26] A.E. Souza, S.R. Teixeira, G.T.A. Santos, E. Longo, Cerâmica 59, 349 (2013) 147.

[27] C.S. Poon, D. Chan, Constr. Build. Mater. 21 (2007) 164.

[28] C.S. Poon, D. Chan, Constr. Build. Mater. 20 (2006) 569.

[29] C.S. Poon, S.C. Kou, L. Lan, Constr. Build. Mater. 16 (2002) 281.

(Rec. 12/09/2018, Rev. 24/10/2018, Ac. 29/10/2018) 